\title{
Remembering our classics: then and now
}

\author{
J. R. Zierath
}

Received: 23 September 2011 / Accepted: 23 September 2011 /Published online: 25 October 2011

(C) Springer-Verlag 2011

Keywords Diabetes · Historical perspectives · Scientific discoveries . Then and now

Who doesn't love the classics? Be it literature, music or art... Shakespeare, Mozart or Monet... everyone has their own favourite. Each of these great talents from the past has had an important impact on today's culture. In their own unique way they have each changed their respective art form and created a new way forward. The field of humanities has its share of classics, and countless enthusiasts flock to libraries, concert halls and museums to celebrate them. Now, with the electronic age, one does not even have to leave the sofa to enjoy these art forms by download.

Classics in literature, music and art are a part of our daily tapestry, but what about the classics in science and medicine that have had a profound effect on how we live our lives today? During one of my first visits to the EASD office in Düsseldorf, the Executive Director of our society, Dr Viktor Jörgens, brought out book after book of classic discoveries in medicine. He reminded me of the great accomplishments of Claude Bernard, Camillo Golgi, Paul Langerhans and Oskar Minkowski, who were all born in the 19th century and made great discoveries in the field of diabetes; they are still remembered by named lectures presented at our annual meetings.

J. R. Zierath $(\bowtie)$

Department of Molecular Medicine and Surgery,

Section of Integrative Physiology, Karolinska Institutet,

von Eulers väg 4, 4th Floor,

17177 Stockholm, Sweden

e-mail: Juleen.Zierath@ki.se
Modern science is moving at such a fast pace that it's a challenge to keep abreast of the latest developments. Young students are faced with enormous numbers of concepts, techniques and methodologies to learn, before they even have the chance to consider where these originated. Diabetologia was first published in 1965, and throughout the years the journal has contributed to the rich history of scientific discovery. For this reason, one of my initiatives in taking over as Editor of the journal was to introduce a series of invited commentaries, which will be presented as a monthly feature called 'Then and now'. Each article will feature a highly cited classic paper (or in some cases, several related papers) from the archives of our journal. The authors of these commentaries have been invited to describe the major findings of these papers and to assess their impact on the field today. The series will cover a diverse range of topics, from the development of assays and algorithms still in use today, to findings that led to a completely new way of thinking about diabetes. I hope that this will narrow the gap between what we knew then and what we know now.

To launch this series, in this issue Bernadette Grayson and Randy Seeley [1] highlight two landmark papers published back-to-back in Diabetologia in 1973 by Douglas Coleman in which, together with Katharine Hummel, he first studied the influence of genetic background on the expression of the obese $(o b)$ gene in the mouse [2], and established that the severity of diabetes depended on modifying genes in the inbred background. He went on to study independently the effects of parabiosis of obese mice with diabetes and normal mice [3], and found that $o b / o b$ mutant mice recognised and responded to a satiety factor produced by $d b / d b$ mice. Inspired by Coleman's work, Jeffrey Friedman and co-workers later identified this satiety factor as leptin in 1994 [4], and through these discoveries new aspects of physiology have emerged. 
Over the years, Diabetologia has published papers that deal with big questions, including whether type 2 diabetes is a disease of the innate immune system. A classic study by John Pickup and co-workers highlighted that an elevated acute-phase response in people with type 2 diabetes may contribute to the accelerated atherosclerosis associated with this disease [5]. Their findings provided evidence that longterm cytokine-mediated acute-phase reaction occurs in type 2 diabetes and is part of a wide-ranging innate immune response. Whether chronic inflammation is a cause or a consequence of type 2 diabetes remains an active question in the field today. In a future 'Then and now', co-authored with José Fernández-Real, John Pickup will look back at his work and discuss what we know now about the relationship between innate immunity, insulin resistance and type 2 diabetes.

'An ounce of prevention is worth a pound of cure' is a classic idiom of relevance for the upcoming 'Then and now' by John Hawley and Martin Gibala, which will highlight the work of Karl-Fredrik Eriksson and Folke Lindgärde [6], who studied the role of diet and exercise in the prevention of type 2 diabetes in a large clinical study (the 6 year Malmö feasibility study). In light of the accumulating evidence for the health-promoting benefits of exercise, strategies to promote lasting changes in behaviour to increase the habitual level of physical activity and diet in individuals at risk for developing diabetes will be discussed.

The homeostasis model assessment was first published in Diabetologia by David Matthews and colleagues in 1985 [7] and has become a standard mathematical tool to assess insulin resistance and beta cell function in humans. Likewise, the method for the radioimmunological determination of human C-peptide in serum was first published in our journal by Lise Heding in 1975 [8] and this established the role of this peptide as a reliable clinical bio-marker to reflect pancreatic insulin secretion. Undoubtedly many investigators and clinicians routinely determine the HOMA index and assess the C-peptide concentration in their patients. Future editions of 'Then and now' will discuss how these tools were designed and explain the science that was applied in their development.

This Editorial offers just a flavour of what is to come. I hope that you will enjoy this series highlighting the different perspectives of our classics and how they might influence our future efforts to understand the pathogenesis, prevention and cure of diabetes. In closing, I would like to thank all of the contributing authors for integrating the past with the present and sharing their views of our field then and now.

\section{References}

1. Grayson BE, Seeley RJ (2012) Deconstructing obesity: the face of fatness before and after the discovery of leptin. Diabetologia. doi:10.1007/s00125-011-2346-7

2. Coleman DL, Hummel KP (1973) The influence of genetic background on the expression of the obese $(o b)$ gene in the mouse. Diabetologia 9:287-293

3. Coleman DL (1973) Effects of parabiosis of obese with diabetes and normal mice. Diabetologia 9:294-298

4. Zhang Y, Proenca R, Maffei M, Barone M, Leopold L, Friedman JM (1994) Positional cloning of the mouse obese gene and its human homologue. Nature 372:425-432

5. Pickup JC, Mattock MB, Chusney GD, Burt D (1997) NIDDM as a disease of the innate immune system: association of acutephase reactants and interleukin-6 with metabolic syndrome X. Diabetologia 40:1286-1292

6. Eriksson KF, Lindgärde F (1991) Prevention of type 2 (non-insulindependent) diabetes mellitus by diet and physical exercise. The 6-year Malmö feasibility study. Diabetologia 34:891-898

7. Matthews DR, Hosker JP, Rudenski AS, Naylor BA, Treacher DF, Turner RC (1985) Homeostasis model assessment: insulin resistance and beta-cell function from fasting plasma glucose and insulin concentrations in man. Diabetologia 28:412-419

8. Heding LG (1975) Radioimmunological determination of human C-peptide in serum. Diabetologia 11:541-548 